\title{
J.-M. Vital (ed): Alternatives à l'arthrodèse lombaire et lombosacrée, Cahier d'enseignement de la SO.F.C.O.T. No. 96 (J. Duparc)
}

\author{
Elsevier Masson, Paris, 2007, 222 pp, nbr. Figs. Cartonné, \\ $€$ 125.00, ISBN: 978-2-84229-844-8
}

\author{
Pierre Kehr
}

Received: 16 August 2009 / Accepted: 18 August 2009 / Published online: 2 September 2009

(C) Springer-Verlag 2009

This book is a complete overview of the possibilities in spine surgeries. In the lumbar spine, the gold standard is fusion, but a major problem is development with time of degenerative lesions at the adjacent level. This pejorative evolution can be explained by the rigidity and also by the lack of lordosis of the fused area or the damage of the articular process. This can be also a natural evolution of a predisposed spine. Many chapters of the book describe this adjacent level on the clinical and mechanical point of view. The sagittal balance is explained. The solutions are discussed: pars repair, interspinous devices, interpedicular ligaments, nucleus replacement, total disc replacement (principles, selection of patients, surgical technique of insertion and complications), total facet joint prosthesis. The end is an opening to the future with the cells culture in lumbar disc disease. Every chapter is written by a wellknown expert on each topic. This book is an interesting focus on the subject and will interest all students and confirmed surgeons concerned by the problem.

Ce livre est un survol complet des possibilités en chirurgie reconstructrice du rachis autres que l'arthrodèse qui est le gold standard. Le problème principal de la fusion est le niveau adjacent souvent compliqué avec le temps de lésions dégénératives. La mauvaise évolution peut être expliquée par la rigidité de la zone d'arthrodèse mais aussi par son manque de lordose et l'altération iatrogène des articulaires postérieures du segment adjacent. Cela peut aussi être l'évolution naturelle d'une colonne lombaire prédisposée. De nombreux chapitres du livre décrivent ce segment adjacent du point de vue clinique mais aussi mécanique avec une particulière attention à l'équilibre sagittal. Les solutions sont exposées et discutées: réparation isthmique, implants interépineux, prothèses nucléiques, prothèses totales de disque (principes, sélection des patients, technique chirurgicale et complications), prothèses totales articulaires postérieures. Le livre se termine sur une ouverture vers le futur avec la culture de cellules discales pour le traitement des discopathies. Chaque chapitre est écrit par un expert reconnu pour le sujet développé. Ce livre est une mise au point intéressante sur la non fusion et s'adresse aux chirurgiens en formation mais aussi confirmés qui sont concernés par ce problème.

No funds were received in support of this study.

Jean-Paul Steib Strasbourg

P. Kehr $(\bowtie)$

ArgoSpine, Strasbourg, France

e-mail:kehrpier@aol.com 